Research Article

\title{
Bulk and Surface Chemical Composition of Wheat Flour Particles of Different Sizes
}

\author{
Jiangtao Lin $\mathbb{D}^{1,2}$ Yujuan Gu $(\mathbb{D})^{1}$ and Ke Bian $\mathbb{D}^{1}$ \\ ${ }^{1}$ College of Food Science and Technology, Henan University of Technology, Zhengzhou 450001, China \\ ${ }^{2}$ Henan Agricultural University, Zhengzhou 450002, China \\ Correspondence should be addressed to Jiangtao Lin; hautlin@126.com and Ke Bian; kebian@163.com
}

Received 8 November 2018; Revised 26 December 2018; Accepted 18 March 2019; Published 22 April 2019

Academic Editor: Kamlesh Shrivas

Copyright (c) 2019 Jiangtao Lin et al. This is an open access article distributed under the Creative Commons Attribution License, which permits unrestricted use, distribution, and reproduction in any medium, provided the original work is properly cited.

Chemical composition and particle size are the critical factors influencing the quality and application of flour. The present study investigated the microstructure and distribution of bulk and surface chemical composition in wheat flour particles of different size. Eight samples of wheat flour of different particle size were obtained from the same native wheat flour by sieving (sieve aperture from 25 to $112 \mu \mathrm{m}$ ). Results from scanning electron microscopy and bulk chemical composition analyze showed that flour particles of different sizes differed in microstructure, protein, and starch composition. Further analysis of protein fractions with varying solubility implied that the relative smaller flour particles (diameter $<48 \mu \mathrm{m}$ ) had higher gluten protein (gliadin and glutenin) ratio (60.88-64.06\%). Furthermore, amino acid analysis showed that glutamic acid was rich in the medium particles. The results of XPS showed that the surface chemical composition of wheat flour of different sizes had no correlation with the bulk chemical composition, indicating that they would have an independent effect on the quality of flour.

\section{Introduction}

Wheat flour is powder obtained from the milling of wheat grains, which is the main raw material for cereal-based food products. The quality of wheat flour, which will directly affect the appearance, taste, and texture of flour foods, is a function of many factors including wheat variety, processing technology, and storage conditions. Currently, flour quality is typically evaluated by measuring the chemical compositions (protein, gluten, starch, and damaged starch content), dough rheological properties (viscoelasticity and extensibility), or directly investigating the performance in food making (steaming, boiling, and baking).

The quality of wheat flour is fundamentally determined by its chemical composition. The major components of wheat flour are protein (approximately 10\%-12\%) and starch (approximately 70-75\%), and the minor components are polysaccharides (approximately 2-3\%) and lipids (approximately $2 \%$ ) [1]. Chemical compositions may affect the flour properties of dough kneading (water absorption rate), gluten network formation, dough properties (hardness, viscosity, elasticity, extensibility, plasticity, water retention, etc.,) and cooking characteristics (shape retention, chewing viscosity, hardness, shrinkage, etc.), which are especially important for Chinese flour food [2-5].

Particle size is also an important parameter of wheat flour [6]. During flour milling, the different processing technologies (grinding strength, separation, and recombination technologies) will produce wheat flour with varying particles (different in particle size and distribution) $[7,8]$. These particles, which may come from the different part of wheat endosperm, inducing significant difference in the chemical compositions, will have different devotion to the whole quality of flour [9]. Previous studies have investigated the effects of protein, gluten, starch, and damaged starch on the quality of wheat flour. In recent years, the effects of flour particle size on the quality of flour and related products have attracted more attention, and the relationship between whole flour particle distribution and overall quality of the flour-based products has also been fully demonstrated $[8,10-12]$. However, due to the heterogeneous structure of the wheat endosperm, particles of different sizes do not 
necessarily have the same chemical compositions, so the relationship between the chemical composition of wheat flour particles of different size and flour quality cannot be established.

X-ray photoelectron spectroscopy (XPS) is one of the most important modern surface chemical analysis methods and can be used for the qualitative and quantitative analysis of the surface chemical composition of unknown samples [13]. In addition to the difficulty in distinguishing arabinoxylans and starch because of their similar chemical structure, XPS can clearly distinguish proteins, starches, and lipids on the surface of flour particles [14]. Particularly, previous studies have demonstrated that the functional properties (water absorption, rehydration, wetting ability, etc.,) and quality characteristics of wheat flour are closely related to the surface chemical composition of wheat flour particles [15] and the surface chemical composition of wheat flour particles would be significantly different from their bulk composition [16-20].

Investigation of the chemical composition in the bulk and surface of flour particles of different sizes is necessary for assessment of the flour quality. With the exception of protein and starch content, protein fractions with different solubility and amino acid compositions were more representative of the bulk chemical composition of flour. The goal of the present study was to investigate the bulk and surface chemical composition in wheat flour particles of different sizes, in order to lay the foundation for the adjustment of flour quality by reconstitution during wheat flour production.

\section{Materials and Methods}

2.1. Chemicals and Reagents. Sodium chloride ( $\geq 99.5 \%)$, ethanol $(\geq 99.9 \%)$, and sodium hydroxide $(\geq 96 \%)$ were purchased from Tianjin Tianli Chemical Reagent Co., Ltd. (Tianjin, China). Concentrated hydrochloric acid (36\%$38 \%$ ) was purchased from Luoyang Chemical Reagent Factory (Luoyang, China). Starch (GO/P) kits $(1 \mathrm{~mL} / \mathrm{vial})$ were purchased from Sigma Aldrich Ltd. (St. Louis, MO, USA). Trisodium citrate $(\geq 99.5 \%)$, citric acid ( $\geq 99.8 \%)$, and ninhydrin $(\geq 95 \%)$ were purchased from SinoPharm Chemical Reagent Co. Ltd. (Shanghai, China). Phenol $(\geq 99 \%)$ was purchased from Xilong Chemical Ltd. (Guangdong, China). Mixed amino acid standard solution $(2.5 \mu \mathrm{mol} / \mathrm{mL}, 5 \mathrm{~mL}, \mathrm{H}$ type $)$ was purchased from Sykam Scientific Instrument Co. Ltd. (Germany).

2.2. Preparation of Wheat Flour Samples. Eight samples of wheat flour particles of different sizes were prepared from the same native flour by sieving. The native flour used was from Su-sanling Flour Co., Ltd. (Taixing, Jiangsu, China), which was obtained by milling medium gluten wheat mixture including $30 \%$ of Jiangsu red wheat, $20 \%$ of Australian white wheat, and $50 \%$ of Jimai 20 with an extraction rate of $51 \%$. The origin and quality characteristics of the three varieties of wheat are presented in Table 1 . The quality indexes of the native flour were as follows: water content,
12.11\%; protein, $11.75 \%$; total starch, $80.65 \%$; and damaged starch, $11.41 \%$ (dry basis).

The native flour was separated by an electric testing sieve (JJSY $30 \times 10$, Shanghai Jiading Cereals and Oils Instrument Co., Ltd.). Flour $(500 \mathrm{~g})$ was weighted and sieved orderly with sieves of 112-, 104-, 99-, 78-, 74-, 48-, 38-, and 25- $\mu \mathrm{m}$ apertures $[10,21]$. The sieving process was finished when the increase of the sieve-through substance was less than 5\%/ min, and eight flour samples with different particle size were obtained and numbered from 1 to 8 according to particle size (Table 2). For better identification, we took \#1, \#2, \#3, and \#4 as large particles, $\# 5$ and $\# 6$ as medium particles, and $\# 7$ and $\# 8$ as small particles.

2.3. Determination of Particle Size Distribution. The particle size distribution of the eight flour samples was measured by a laser particle size analyzer (BT-9300H laser particle size analyzer, Dandong Buite Instrument Co., Ltd.), and the results are expressed with D50 and D90 (Table 2) [22].

2.4. SEM Observation. The microstructures of wheat flour particles were observed by a scanning electron microscope (Quanta250FEG). A representative of each flour sample was fixed on the load table by double-sided adhesive tape, and then coated with $\mathrm{Au}$ to provide conductivity [20]. The observation distance and contrast of the scanning were adjusted to get the best photographic results, and the microstructure image of each sample was observed at 2000× magnification.

2.5. Bulk Chemical Composition Analysis. The total starch content and damaged starch content were determined according to AACC-approved methods (76-13 and 76-31). The total nitrogen content (TN) was determined by the Kjeldahl method (Kjeltec TM 8400, Sweden), and the protein content was calculated according to the AACC 46-10 method $(\mathrm{TN} * 5.7)$. Proteins with different solubility, including albumin, globulin, gliadin, and glutenin, were extracted with pure water, $10 \%$ sodium chloride, $70 \%$ ethanol, and $0.2 \%$ sodium hydroxide, respectively. The amino acid content was determined using an automatic amino acid analyzer (S-433D, Germany) according to AACC methods (07-01 and 07-11).

2.6. Surface Chemical Element and Group Analysis. The surface chemical composition of flour particles was analyzed by an X-ray photoelectron spectrum analyzer with a monochromatic X-ray source. A small amount of flour sample was placed on aluminum foil with double-sided adhesive tape and then fixed by a tablet machine. The nonfixed powder was removed. The prepared sample was put flatly in a stainless-steel container in the working chamber of the X-ray photoelectron spectrometer (ESCALAB $250 \mathrm{Xi}$, Thermo Fisher Scientific).

The working conditions were as follows: the scanning range was from 0 to $1400 \mathrm{eV}$; the pressure in the working chamber during analysis was $<10^{-7}$ Torr; the takeoff angle 
TABLE 1: Origin and quality characteristics of wheat used for flour samples preparation.

\begin{tabular}{lccccc}
\hline Wheat cultivars & Origin & Features & Protein content (\%) & Wet gluten content (\%) & Sedimentation number (mL) \\
\hline SM188 & Jiangsu, China & Red, soft & 11.46 & 27.40 & 31.50 \\
ASW & Australia & White, soft & 10.80 & 28.90 & 36.10 \\
JM 20 & Jinan, China & White, hard & 14.30 & 31.60 & 54.20 \\
\hline
\end{tabular}

TABLE 2: Flour samples and their passed and unpassed sieves.

\begin{tabular}{|c|c|c|c|c|c|c|c|c|}
\hline Flour samples & $\# 1$ & $\# 2$ & $\# 3$ & $\# 4$ & $\# 5$ & $\# 6$ & $\# 7$ & $\# 8$ \\
\hline Passed sieves aperture $(\mu \mathrm{m})$ & 112 & 104 & 99 & 78 & 74 & 48 & 38 & 25 \\
\hline Unpassed sieves aperture $(\mu \mathrm{m})$ & 104 & 99 & 78 & 74 & 48 & 38 & 25 & - \\
\hline Particle size distribution D50 $(\mu \mathrm{m})$ & 42.42 & 32.48 & 27.44 & 26.30 & 23.32 & 17.33 & 14.57 & 13.63 \\
\hline Particle size distribution D90 $(\mu \mathrm{m})$ & 148.70 & 138.00 & 131.00 & 126.20 & 67.92 & 37.19 & 35.46 & 31.98 \\
\hline
\end{tabular}

of the photoelectrons was perpendicular to the sample; the analyzer was operated with a pass energy of $65 \mathrm{eV}$ on the selection of XPS spectrum; the step size was $0.1 \mathrm{eV}$; the analyzed region was $300 \mu \mathrm{m} \times 700 \mu \mathrm{m}$; the dwell time was $1000 \mathrm{~ms}$; and a Shirley baseline was used for the background subtraction $[14,16]$. The binding energy of the narrow-spectrum scanning corresponded to the chemical functional group, and the sensitivity factor method was used in the quantitative analysis of elements and groups [14].

2.7. Statistical Analysis. The data were presented as the mean \pm standard deviation (SD). The calculation of mean and $\mathrm{SD}$ was based on descriptive statistical analysis via SPSS20.0 software. Linear correlation analysis was conducted using Origin 8.5 software, and the XPS data processing was conducted using XPS peak-fitting software.

\section{Results and Discussion}

3.1. Particle Size Distribution of Flour Samples. The results of particle size distribution analysis are shown in Table 2. The mean granule diameter (D50) of wheat flour particles of different size varied from 42.42 to $13.63 \mu \mathrm{m}$, while D90 ranged from 148.70 to $31.98 \mu \mathrm{m}$ (more details in Supplementary data Figure S1).

3.2. Microstructure Analysis. When the wheat grains were milled, the wheat endosperm was split and diverse kinds of flour particles were formed. The microstructures of eight flour samples were observed using SEM (Figures 1(a)-1(h)). Collectively, the compositions of these particles mainly include endosperm lumps (whole endosperm cell aggregates), whole starch granules, damaged starch granules, and irregular protein fragments.

Comparing the eight images to each other, it was found that the large flour particles $(\# 1, \# 2, \# 3$, and \#4) were composed primarily of endosperm lumps; the medium particles (\#5) included small endosperm lumps and large starch granules; the smaller particles, \#6, mainly consisted of whole starch granules and a small amount of protein fragments; \#7 was composed of starch granules, damaged starch granules, and protein fragments; and \#8, the smallest particle, was mainly composed of damaged starch and protein fragments. Visual observation implied that flour particles of varying size had significant differences in protein and starch contents, and different flour particles seemed to have different chemical compositions in both bulk and surface.

3.3. Protein and Starch Composition Analysis. Wheat endosperm is mainly composed of protein and starch (integrated or damaged), so protein and starch contents were investigated first to study bulk compositions of different flour particles. Figure 2 shows the changes of protein, starch, and damaged starch content of wheat flour particles. With decreasing particle size, the protein content increased first in large particles $(\# 1 \# 4$, from $11.45 \%$ to $13.91 \%$ ), then decreased sharply in medium particles (\#5 and \#6, from $11.72 \%$ to $9.75 \%$ ) and later gradually increased again in small particles (\#7 and \#8, from $10.64 \%$ to $11.39 \%$ ) (Figure 2(a)). The protein contents of samples \#1 and \#8 were close to the native flour (11.75\%). The highest protein content $(13.91 \%)$ was found in sample \#4, while sample \#6 exhibited the lowest protein content $(9.75 \%)$.

Different from protein content, both the starch content and damaged starch content increased with the decreasing particle size (Figures 2(b) and 2(c)), implying that more isolated starch granules and damaged starch entered into the small particles during the wheat-milling procedure. The higher starch content of small particles (\#6-\#8) was mainly caused by the increase of damaged starch, which was consistent with the SEM observation. Moreover, it was surprising to find that the sum of the starch content (subtracting the damaged starch content) and protein content of all samples were all approximately $82 \%$ (Figure 2(e)), which was nearly equal to that of the original flour.

In combination with SEM, the changes of protein and starch contents of flour samples might be explained as follows: the large flour particles were dominated by endosperm lumps, so the protein content of \#1 (11.45\%), the largest particle, was close to that of the whole endosperm $(11.75 \%)$. In flour samples \#2, \#3, and \#4, the endosperm 


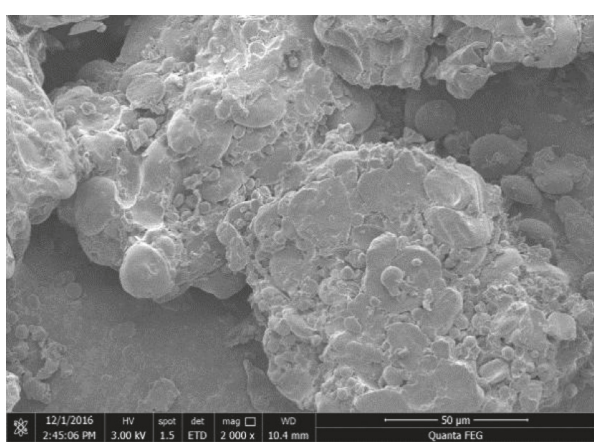

(a)

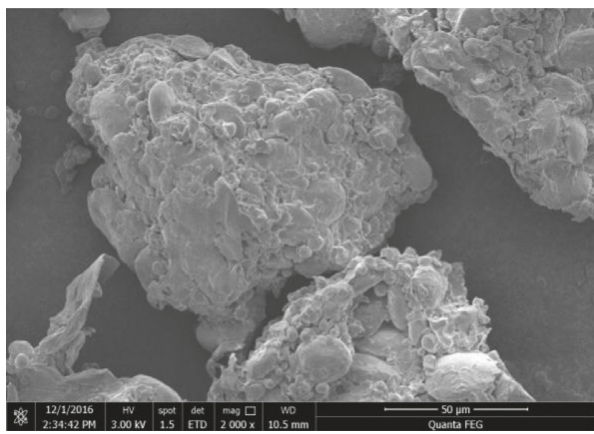

(c)

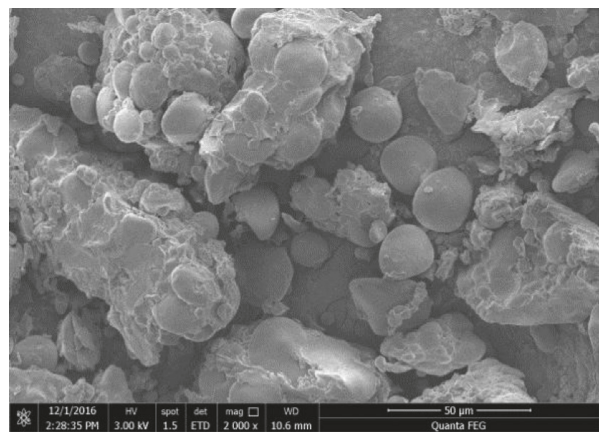

(e)

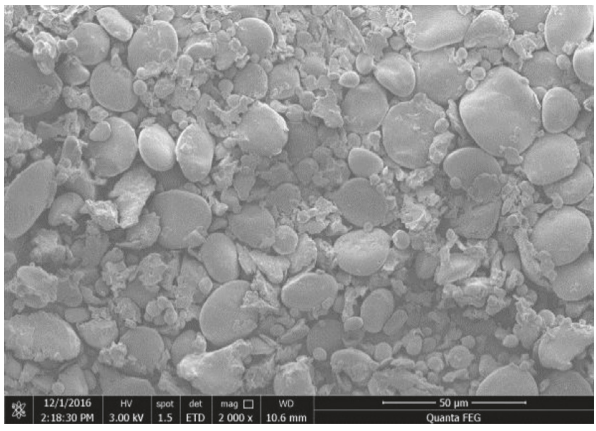

(g)

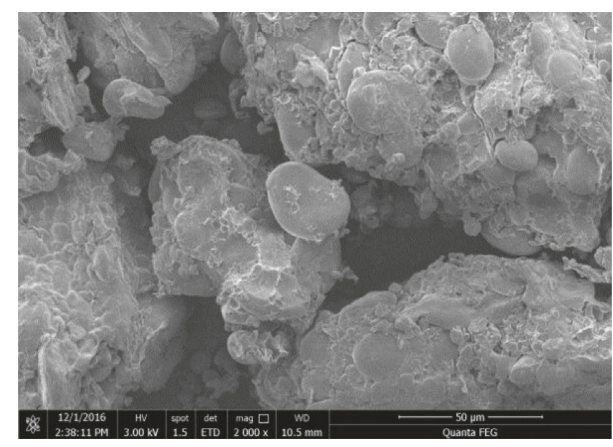

(b)

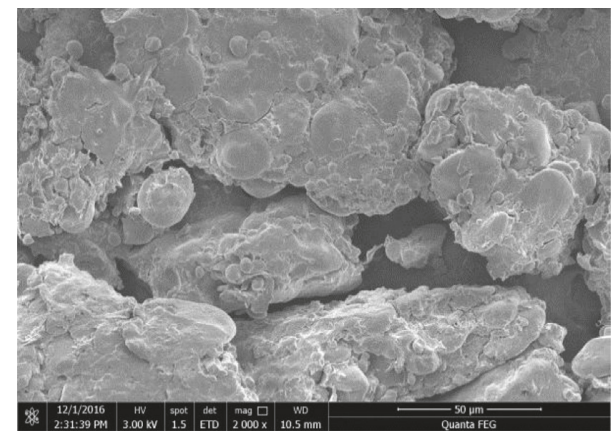

(d)

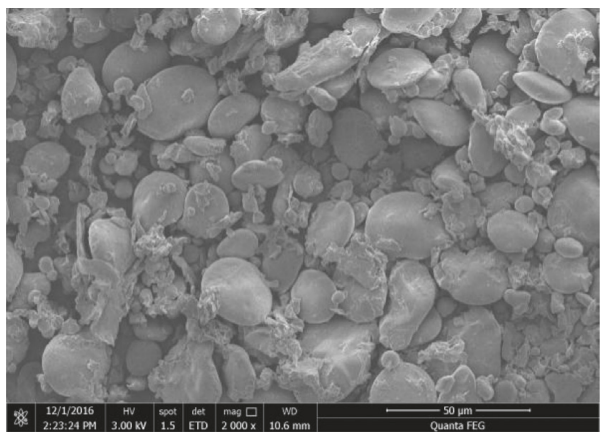

(f)

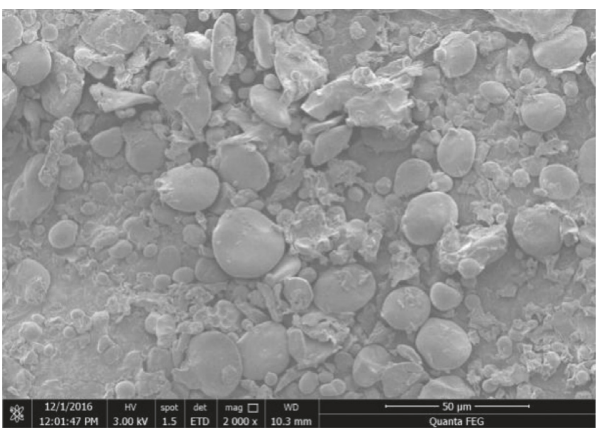

(h)

FIGURE 1: Scanning electron microscopy images of flour particles of different sizes: (a) \#1; (b) \#2; (c) \#3; (d) \#4; (e) \#5; (f) \#6; (g) \#7, and (h) \#8.

lumps were broken up, and some starch granules fell off from the endosperm lumps, resulting in a decrease in starch content (Figure $2(\mathrm{~d}))(70.81 \%-68.62 \%)$ and a gradual increase in the protein content $(12.41 \%-13.91 \%)$. With the further decrease of particle size (\#5 and \#6), the proportion of endosperm lumps decreased, while the damaged starch proportion sharply increased, so protein content decreased again $(11.72 \%-9.75 \%)$. When the particle size further decreased (\#7 and \#8), the proportion of protein fragments began to increase, so the protein content emerged increasing trend again $(\# 7,10.64 \%$; $\# 8,11.39 \%)$ until it approached the whole endosperm level (11.75\%). 


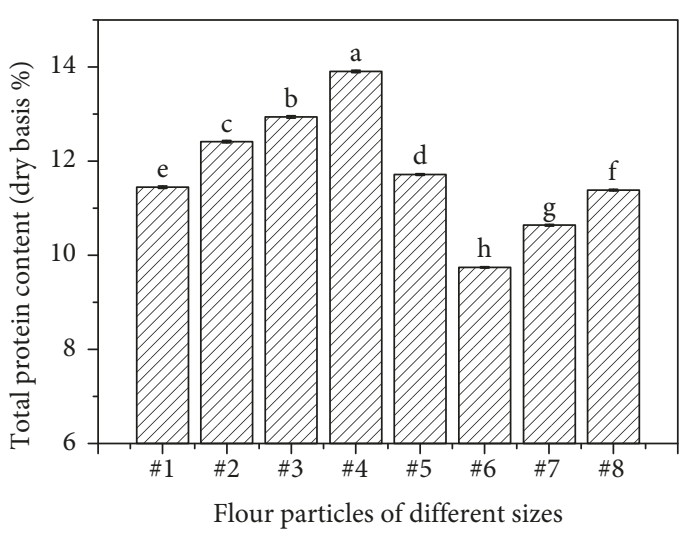

(a)

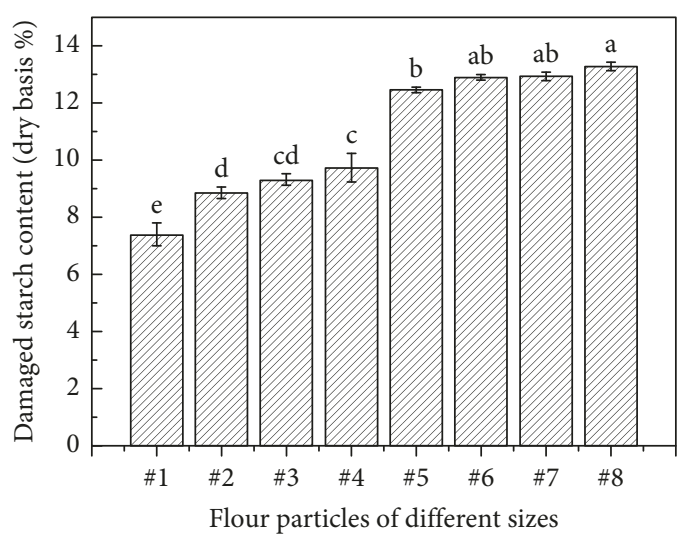

(c)

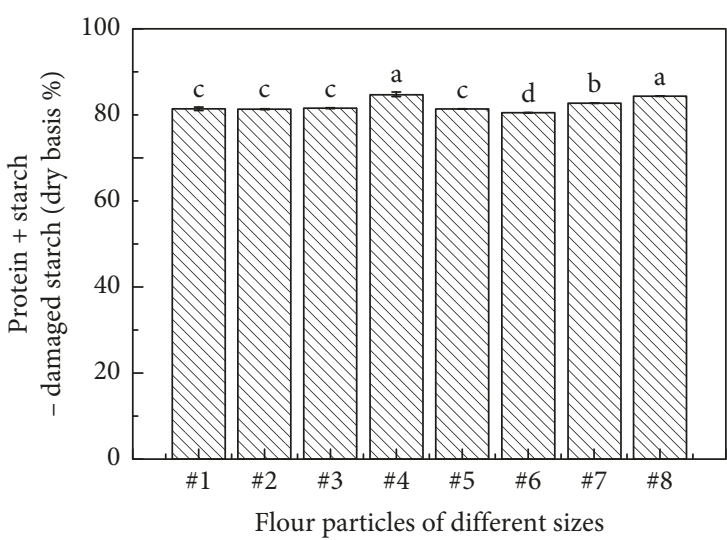

(e)

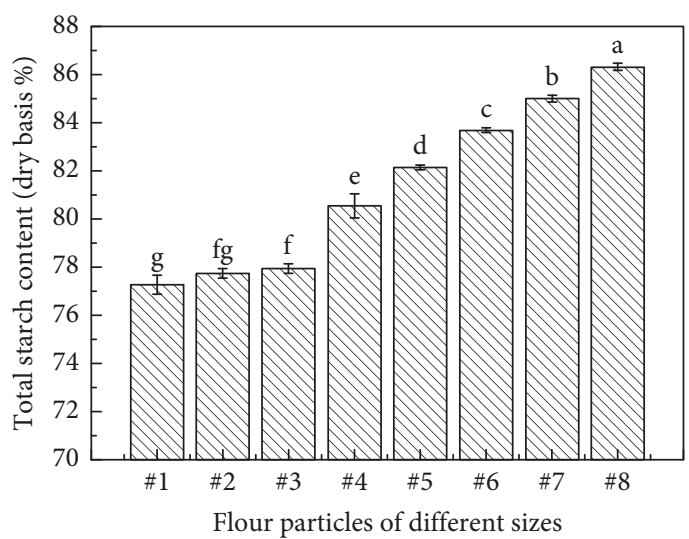

(b)

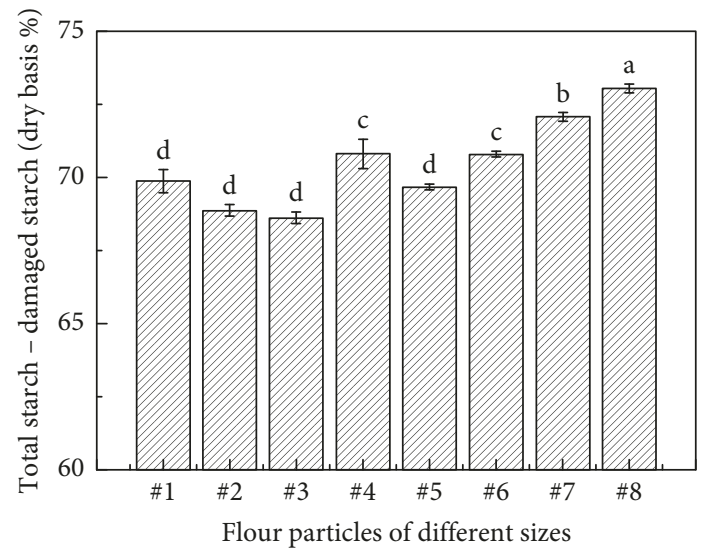

(d)

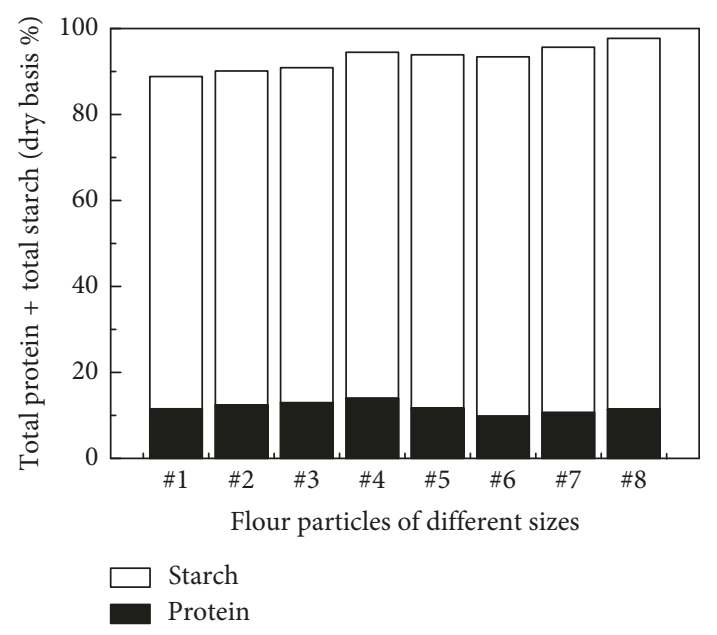

(f)

FIgURE 2: The protein and starch content of flour particles of different sizes. (a) total protein content; (b) total starch content; (c) damaged starch content; (d) integrated starch content (damaged starch subtracted); (e) total protein and integrated starch content (damaged starch subtracted); (f) total protein and total starch content.

The sum of protein and starch contents of eight flour samples is shown in Figure 2(f). The value in the smallest particle (\#8,97.71\%) was higher compared to the largest particle (\#1, 88.82\%), indicating that lipids, oligosaccharides, and other nonstarch and nonprotein ingredients mainly constituted the endosperm lump structure, but not isolated and mixed with small particles (damaged starch and protein fragments).
3.4. Analysis of Proteins with Different Solubilities. When different solvents were used, wheat proteins could be separated into albumin, globulin, gliadin, and glutenin according to Osborne protein fractionation. These proteins have great differences in molecular weight, structure, and properties and also have significant differences in their influence on the quality characteristics of flour. Glutenin 
contributes to the hydration, elasticity, and antiextensibility of dough, while gliadin contributes to stickiness and extensibility. Globulin and albumin, which belong to nongluten proteins, have little effect on flour quality [23-25].

The proportions of four proteins from eight flour samples are presented in Figure 3. The results showed that the albumin content was higher in the small particles (\#7, $30.85 \%$; \#8, 30.01\%), but had the lowest content in the medium particles $(\# 5,17.19 \%)$. Globulin content was higher in samples \#1 and \#6 (\#1, 7.93\%; \#6, 8.16\%), but had no significant difference in other samples. Gliadin content was relatively low in samples \#2, \#3, \#4, and \#5 (only $18 \%-19 \%)$, but reached nearly $30 \%$ in small particles (\#6, 31.22\%; \#7, 29.93\%; \#8, 29.49\%). The distribution of glutenin exhibited a similar trend to gliadin: glutenin content was lower in large and medium particles (\#1, 28.22\%; \#2, 26.86\%; \#3, 25.96\%; \#4, 25.75\%; \#5, 25.64\%) but nearly $32 \%$ (\#6, 32.84\%; \#7, 31.51\%; \#8, 31.39\%) in the small particles. Glutenin and gliadin were the main proteins composed of gluten during dough making, indicating that the small particles of wheat flour had greater contribution to the forming of gluten.

3.5. Amino Acid Compositions. Amino acids are the essential units of proteins, and each amino acid has special functional properties. Generally, cysteine and methionine will affect the molecular interaction of proteins; proline has a great influence on the secondary structure of protein molecules, and glutamic acid, proline, leucine, glycine, and valine are the primary constituents of gluten, which have significant effect on the rheological properties of dough [26].

Results of amino acid composition analysis of flour particles of different size are shown in Table 3. For better comparison, the amino acid content was expressed by the percentage of amino acid to total protein. According to their distribution trend in eight samples, the amino acids were divided into four groups: I, Asp, Arg, Gly, Ile, Lys, and Thr; II, Met, Cys, Ala, Tyr, His, Val, Ser, Phe, and Leu; III, Pro; and IV, Glu. For group I, the contents of these amino acids in the eight samples had no significant change. For group II, with the decrease of flour particle size, the contents of amino acids decreased first in large particles, then increased in medium and finally decreased again in small particles. All of the group II amino acids had the lowest content in \#2 or \#3 samples and the highest content in \#7 samples. Moreover, group III (proline) and group IV (glutamic acid) had obvious discrimination with other groups. Proline was lacking significantly in sample \#6 (5.42\%), while glutamic acid, the most abundant amino acid in wheat grain (accounting for about a third of the total protein), was obviously abundant in sample \#4 (39.96\%) (more details in Supplementary Data Figure S2).

Some studies have demonstrated that proline has a great effect on the secondary structure of protein [27], so it could be inferred that the flour particle (\#6) serious lacking of proline may have a unique protein structure compared with others. On the contrary, flour particles having higher glutamate content (\#4) meant relatively simple structure because of the lower content of other amino acids. These differences will bring uncertain influence on the quality of flour.

3.6. Surface Chemical Composition Analysis. Compared to bulk chemical composition, few studies have been carried out on the surface chemical composition of wheat flour. Although it has been demonstrated that the surface chemical composition of flour is closely related to water absorption and hydration during the formation of the dough [28-32], the influence of surface chemical composition on flour quality is still not clear.

The surface chemical composition of flour particles of different size was analyzed by the XPS method, and the results are shown in Figure 4 (represented by \#8 sample). Five elements, $\mathrm{C}, \mathrm{O}, \mathrm{N}, \mathrm{P}$, and $\mathrm{S}$, were selected for analysis (Figure 4(a)). Elements $\mathrm{C}\left(\mathrm{C}_{1 \mathrm{~s}}, 284.6 \mathrm{eV} ; 286.5 \mathrm{eV} ; 287.9 \mathrm{eV}\right)$ and $\mathrm{O}\left(\mathrm{O}_{1 \mathrm{~s}}, 531.4 \mathrm{eV} ; 532.6 \mathrm{eV} ; 533.3 \mathrm{eV}\right)$ were both decomposed to three subpeaks, while $\mathrm{N}$ decomposed to two subpeaks $\left(\mathrm{N}_{1 \mathrm{~s}}, 399.8 \mathrm{eV} ; 401.9 \mathrm{eV}\right)$ by high-resolution narrow-region scanning (Figures $4(\mathrm{~b})-4(\mathrm{~d})$ ).

The relative contents of the five chemical elements (100.01\% in total) and functional groups of flour particles were calculated by the method of standard sample sensitivity factor [20], and the results are shown in Table 4 and Figure 5. The relative contents of $\mathrm{C}, \mathrm{O}, \mathrm{N}, \mathrm{P}$, and $\mathrm{S}$ of the eight samples were $\quad 71.50 \%-74.14 \%, \quad 20.08 \%-22.63 \%, \quad 4.89 \%-5.53 \%$, $0.22 \%-0.42 \%$, and $0.29 \%-0.37 \%$, respectively.

Functional groups are atomic or atomic groups that determine the chemical properties of organic compounds. Carbon-containing, nitrogen-containing, and oxygencontaining functional groups comprised the basic composition of protein and starch molecules that will have strong relevance with flour quality. With decreasing particle size, the variation of the five functional groups contents in the eight samples of different particle size was significantly different.

(1) Carbon-containing functional groups (Figure 5(a)). With decreasing particle size, the functional group content of $\mathrm{C}_{1 \mathrm{~s}}$ in peak 1 (C-C, C-H) and peak 3 $(\mathrm{O}=\mathrm{C}-\mathrm{OH}, \mathrm{O}=\mathrm{C}-\mathrm{OR})$ had no significant fluctuation, while peak 2 functional groups had an obvious variation. Medium particles had more functional groups of $\mathrm{C}-\mathrm{O}, \mathrm{C}-\mathrm{N}, \mathrm{O}-\mathrm{C}-\mathrm{O}, \mathrm{O}=\mathrm{C}-\mathrm{O}$, and $\mathrm{O}=\mathrm{C}-\mathrm{N}$, which reached the maximum in sample \#5 (27.98\%).

(2) Oxygen-containing functional groups (Figure 5(b)). The functional group content of the three subpeaks of $\mathrm{O}_{1 \mathrm{~s}}$ had the same variation trend with the decrease of particle size; all had the highest content in large particle sample \#1 (peak 1, 6.62; peak 2, 8.77; peak 3, 6.23; \%) and the lowest content in medium particle sample \#5 (peak 1, 4.91; peak 2, 6.82; peak 3, $5.12 ; \%)$. 


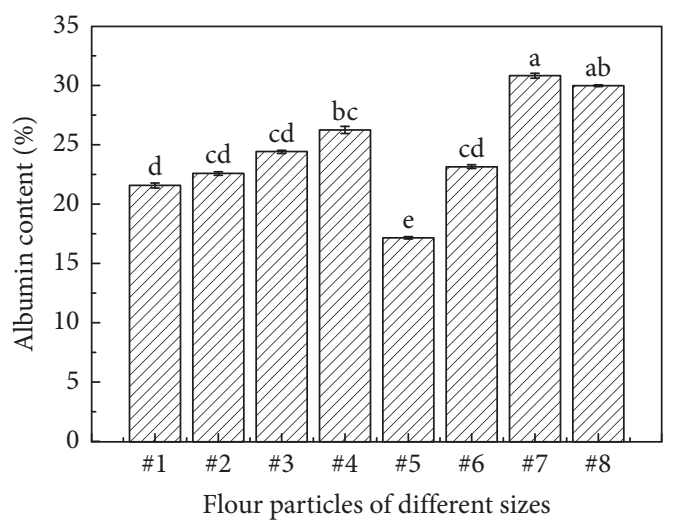

(a)

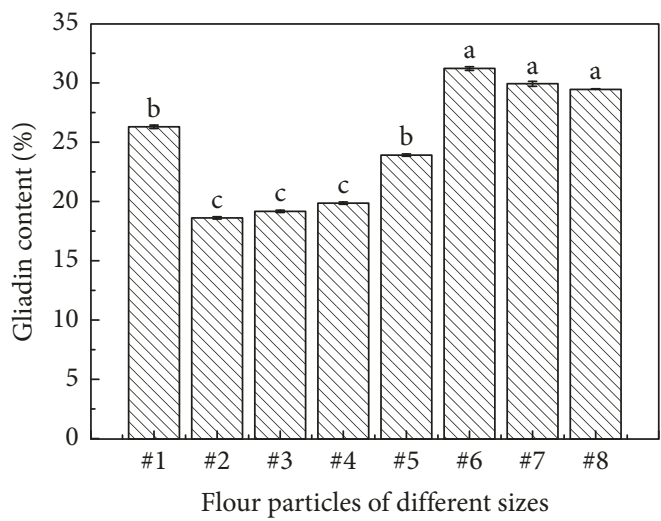

(c)

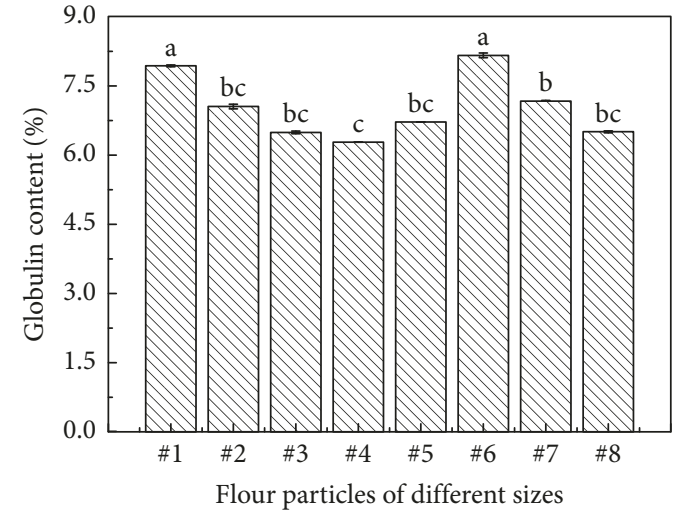

(b)

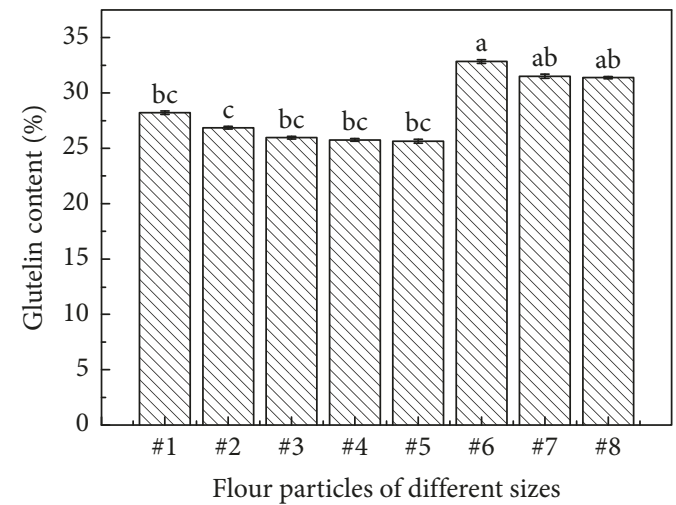

(d)

FIGURE 3: The content of protein composition of flour particles of different sizes. (a) albumin content; (b) globulin content; (c) gliadin content; (d) glutenin content.

TABLE 3: Amino acid content of flour particles of different sizes (percentage of total protein).

\begin{tabular}{lcccccccccc}
\hline Group & Amino acid & $\# 1$ & $\# 2$ & $\# 3$ & $\# 4$ & $\# 5$ & $\# 6$ & $\# 7$ & $\# 8$ & SD \\
\hline \multirow{4}{*}{ I } & Thr & 2.40 & 2.00 & 1.391 & 1.71 & 1.94 & 1.69 & 2.11 & 1.70 & 0.29 \\
& Lys & 2.38 & 2.12 & 2.25 & 2.02 & 1.77 & 2.55 & 2.73 & 2.31 & 0.30 \\
& Gly & 3.46 & 3.01 & 3.09 & 3.08 & 3.18 & 3.40 & 3.44 & 3.01 & 0.18 \\
& Ile & 3.64 & 3.24 & 4.27 & 3.50 & 3.71 & 4.05 & 3.82 & 3.25 & 0.34 \\
& Arg & 3.47 & 3.96 & 3.60 & 4.10 & 2.84 & 3.18 & 2.90 & 3.75 & 0.46 \\
& Asp & 4.83 & 4.50 & 4.45 & 4.46 & 4.13 & 4.63 & 3.79 & 4.44 & 0.30 \\
\hline & Met & 1.17 & 1.18 & 1.10 & 1.46 & 1.66 & 1.80 & 1.90 & 1.29 & 0.29 \\
& Cys & 1.21 & 0.87 & 1.31 & 1.59 & 2.68 & 2.53 & 2.46 & 1.76 \\
& Ala & 2.46 & 1.98 & 1.61 & 2.06 & 2.21 & 2.66 & 2.74 & 2.07 \\
II & Tyr & 2.49 & 2.49 & 2.02 & 2.55 & 2.97 & 3.16 & 2.92 & 2.44 \\
& His & 3.07 & 2.98 & 2.30 & 2.81 & 3.23 & 3.51 & 2.95 & 3.15 & 0.35 \\
& Val & 3.74 & 3.51 & 3.06 & 3.97 & 4.50 & 4.90 & 4.52 & 3.81 & 0.33 \\
& Ser & 4.48 & 4.09 & 3.32 & 3.66 & 4.00 & 4.42 & 4.67 & 4.13 & 0.79 \\
& Phe & 4.85 & 4.29 & 4.39 & 4.69 & 5.42 & 5.69 & 5.23 & 4.15 & 0.53 \\
& Leu & 5.37 & 4.71 & 4.61 & 4.69 & 5.34 & 5.56 & 5.84 & 4.34 & 0.50 \\
\hline III & Pro & 8.30 & 8.60 & 8.27 & 8.40 & 6.67 & 5.42 & 7.02 & 7.67 & $\mathbf{1 . 0 5}$ \\
\hline IV & Glu & 33.55 & 36.65 & 38.57 & 39.96 & 34.89 & 35.00 & 35.11 & 35.44 & $\mathbf{2 . 0 1}$ \\
\hline
\end{tabular}

(3) Nitrogen-containing functional groups (Figure 5(c)). With decreasing particle size, the two subpeaks of $\mathrm{N}_{1 \mathrm{~s}}$ also showed the same trend: first, sharply decreasing first and then increasing; the difference between the two curves was that the functional groups of peak $1\left(\mathrm{O}=\mathrm{C}-\mathrm{NH}, \mathrm{O}=\mathrm{C}-\mathrm{NH}_{2}\right)$ were rich in small particles (samples \#6, \#7, and \#8), while those of peak $2\left(\mathrm{C}^{-\mathrm{NH}_{3}}{ }^{+}\right)$were abundant in large particles (samples \#1 and \#2), indicating that the protein content on the surface of medium flour particles was lower than that on large and small particles. 


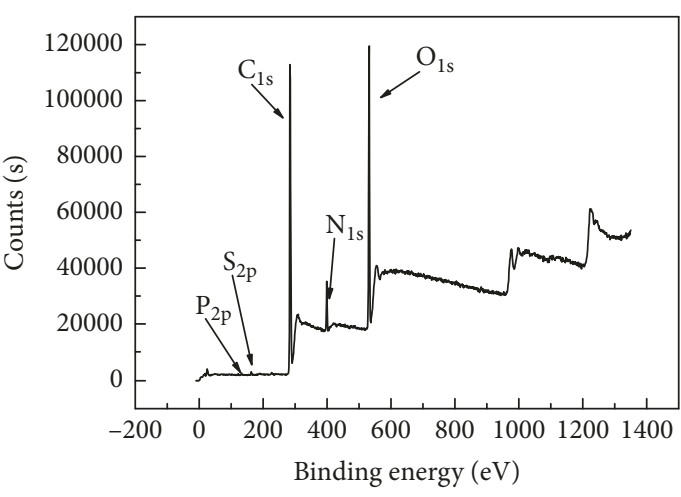

(a)

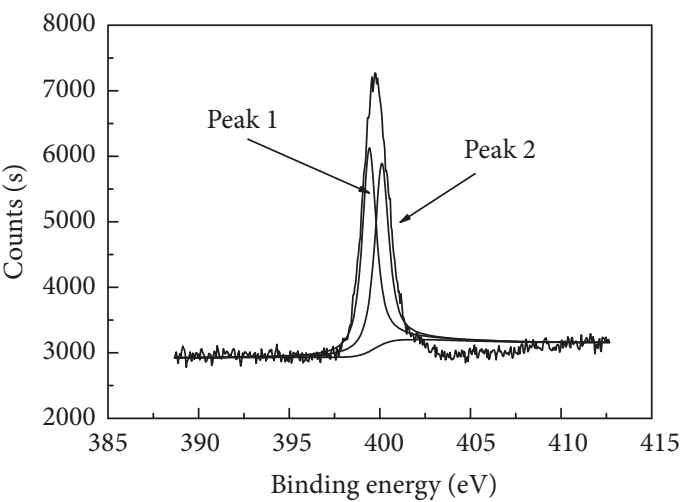

(c)

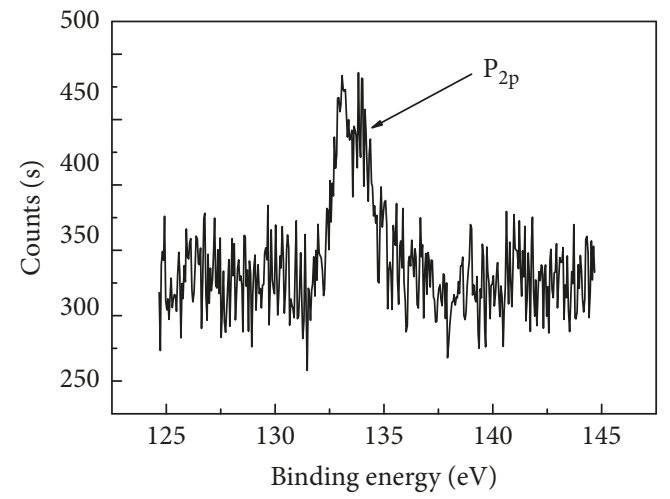

(e)

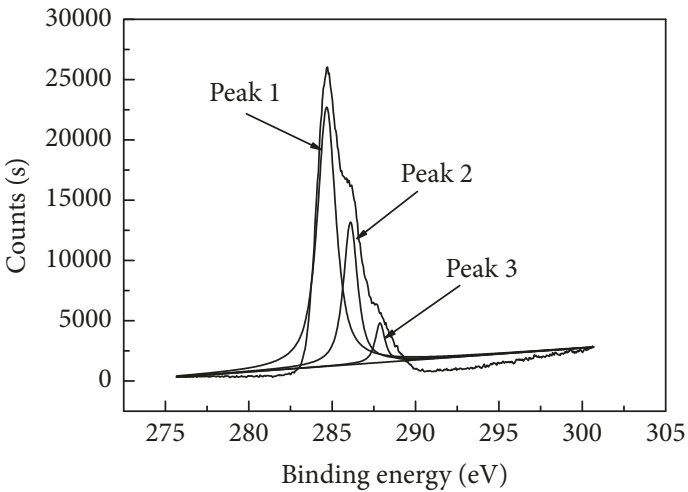

(b)

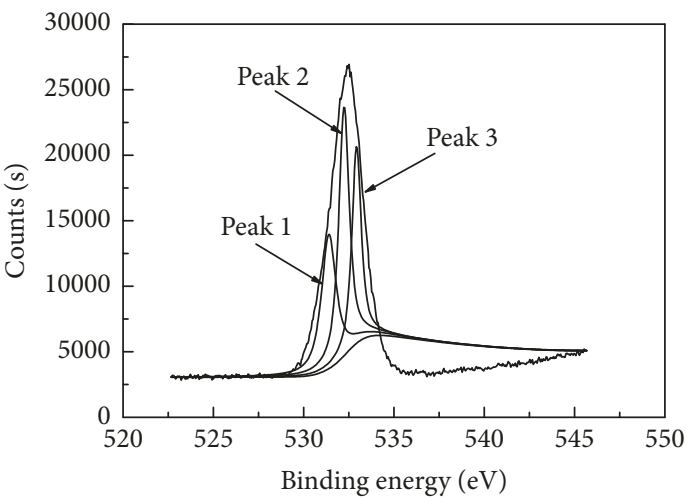

(d)

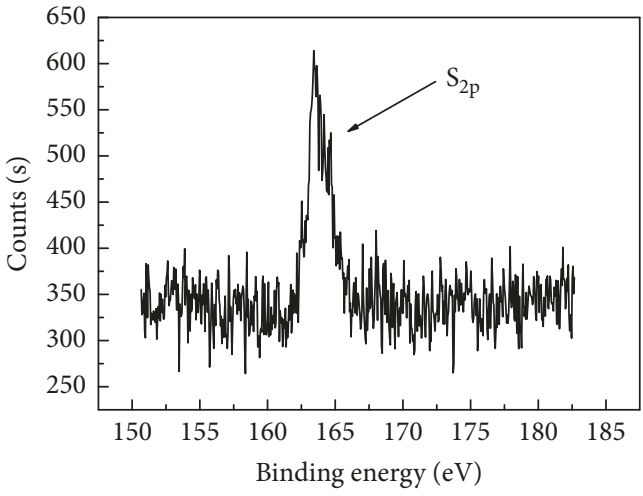

(f)

FiguRE 4: XPS spectrum of flour particles (\#8) with survey scans (a) and decomposition of $C_{1 s}(b), N_{1 s}(c), O_{1 s}(d), P_{2 p}(e)$, and $S_{2 p}$ (f) subpeaks.

(4) Phosphorus and sulphur functional groups (Figure 5(d)). Both $\mathrm{P}_{2 \mathrm{p}}$ and $\mathrm{S}_{2 \mathrm{p}}$ exhibited lower content in large particles (samples \#1 and \#2) and higher content in medium and small particles.

3.7. Relationship between Bulk Chemical Composition and Surface Chemical Composition. A contrasting analysis was designed to provide the correlation between bulk and surface chemical composition. The functional groups on the surface were linked to the amino acid side-chain, for example, the content of nitrogen-containing functional groups might have consistency to the content of nitrogencontaining amino acids in side-chain. The relationship between functional groups and the corresponding amino acids is shown in Table 5. The correlation analysis between the functional groups composition on the particle surface (the result of XPS determination) and amino acid composition (the result of bulk composition analysis) of flour with particles of different size was investigated subsequently. Compared with protein content (bulk composition analysis) variation, the nitrogen-containing functional groups on the surface of flour particles showed an entirely different variation in eight flour samples, suggesting that the surface chemical composition of flour particles scarcely had any correlation with the bulk chemical composition (more details in Supplementary Data Figure S3). 
TABLE 4: The functional group content of $\mathrm{C}, \mathrm{O}, \mathrm{N}, \mathrm{P}$, and $\mathrm{S}$ on the surface chemical composition of flour particles of different sizes (\%).

\begin{tabular}{|c|c|c|c|c|c|c|c|c|c|c|c|c|}
\hline $\begin{array}{l}\text { Binding } \\
\text { energy } \\
(\mathrm{eV}) \\
\end{array}$ & Element & & Functional group & $\# 1$ & $\# 2$ & $\# 3$ & $\# 4$ & $\# 5$ & \#6 & $\# 7$ & $\# 8$ & SD \\
\hline 285.2 & $\mathrm{C}_{1 \mathrm{~s}}$ & & & 71.50 & 73.25 & 72.58 & 72.97 & 74.14 & 71.77 & 72.17 & 71.80 & 0.89 \\
\hline 284.6 & & Peak 1 & $\mathrm{C}-\mathrm{C}, \mathrm{C}-\mathrm{H}$ & 49.55 & 49.37 & 49.31 & 47.48 & 46.70 & 46.77 & 47.46 & 49.26 & 1.25 \\
\hline 286.5 & & Peak 2 & $\mathrm{C}-\mathrm{O}, \mathrm{C}-\mathrm{N}, \mathrm{O}-\mathrm{C}-\mathrm{O}, \mathrm{O}=\mathrm{C}-\mathrm{O}, \mathrm{O}=\mathrm{C}-\mathrm{N}$ & 19.23 & 20.93 & 21.48 & 23.82 & 27.98 & 25.4 & 23.49 & 20.69 & 2.87 \\
\hline 287.9 & & Peak 3 & $\mathrm{O}=\mathrm{C}-\mathrm{OH}, \mathrm{O}=\mathrm{C}-\mathrm{OR}$ & 3.36 & 3.24 & 3.09 & 3.07 & 2.95 & 3.17 & 3.58 & 3.90 & 0.31 \\
\hline 532.3 & $\mathrm{O}_{1 \mathrm{~s}}$ & & & 22.63 & 21.31 & 21.27 & 21.17 & 20.08 & 22.03 & 21.63 & 22.06 & 0.77 \\
\hline 531.4 & & Peak 1 & $\mathrm{O}=\mathrm{C}-\mathrm{OH}, \mathrm{O}=\mathrm{C}-\mathrm{N}, \mathrm{O}=\mathrm{C}-\mathrm{O}$ & 6.62 & 6.29 & 6.59 & 5.80 & 4.91 & 5.78 & 6.06 & 6.07 & 0.55 \\
\hline 532.6 & & Peak 2 & $\mathrm{C}-\mathrm{OH}, \mathrm{C}-\mathrm{O}-\mathrm{C}$ & 8.77 & 8.38 & 8.39 & 8.39 & 6.82 & 7.65 & 7.59 & 7.99 & 0.62 \\
\hline 533.3 & & Peak 3 & $\mathrm{O}=\mathrm{C}-\mathrm{OH}$ & 6.23 & 5.65 & 5.55 & 6.11 & 5.12 & 5.40 & 5.75 & 5.57 & 0.36 \\
\hline 399.9 & $\mathrm{~N}_{1 \mathrm{~s}}$ & & & 5.36 & 4.89 & 5.53 & 5.20 & 5.10 & 5.47 & 5.45 & 5.39 & 0.22 \\
\hline 399.8 & & Peak 1 & $\mathrm{O}=\mathrm{C}-\mathrm{NH}, \mathrm{O}=\mathrm{C}-\mathrm{NH}_{2}$ & 2.63 & 2.52 & 2.34 & 2.24 & 2.43 & 2.73 & 2.78 & 2.99 & 0.25 \\
\hline 401.9 & & Peak 2 & $\mathrm{C}-\mathrm{NH}_{3}^{+}$ & 2.97 & 2.94 & 2.45 & 2.27 & 2.20 & 2.22 & 2.51 & 2.68 & 0.31 \\
\hline 133.3 & $P_{2 p}$ & & & 0.22 & 0.27 & 0.31 & 0.35 & 0.37 & 0.37 & 0.42 & 0.38 & 0.07 \\
\hline 133.1 & & & & 0.26 & 0.32 & 0.40 & 0.45 & 0.43 & 0.45 & 0.43 & 0.44 & 0.07 \\
\hline 164.0 & $S_{2 p}$ & & & 0.29 & 0.30 & 0.32 & 0.31 & 0.32 & 0.36 & 0.34 & 0.37 & 0.03 \\
\hline 163.6 & & & & 0.35 & 0.36 & 0.40 & 0.39 & 0.36 & 0.43 & 0.35 & 0.43 & 0.03 \\
\hline
\end{tabular}

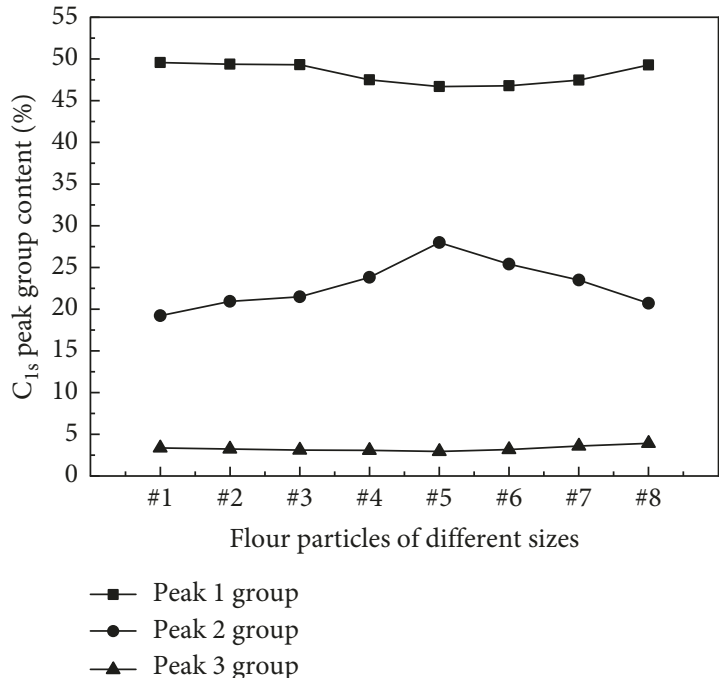

(a)

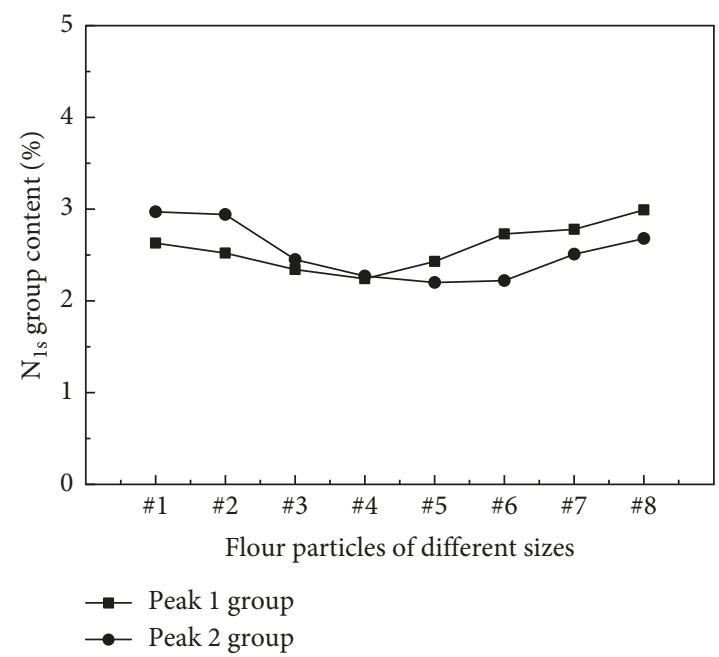

(c)

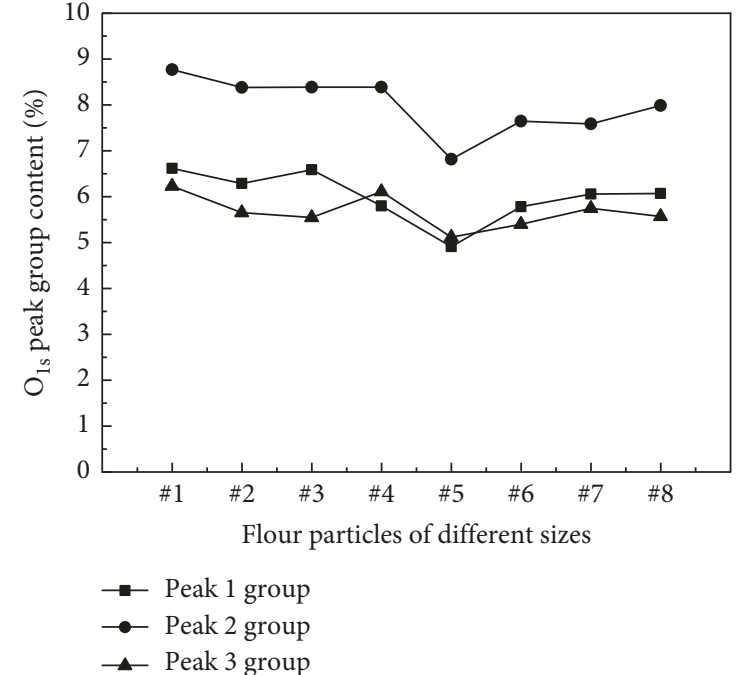

(b)

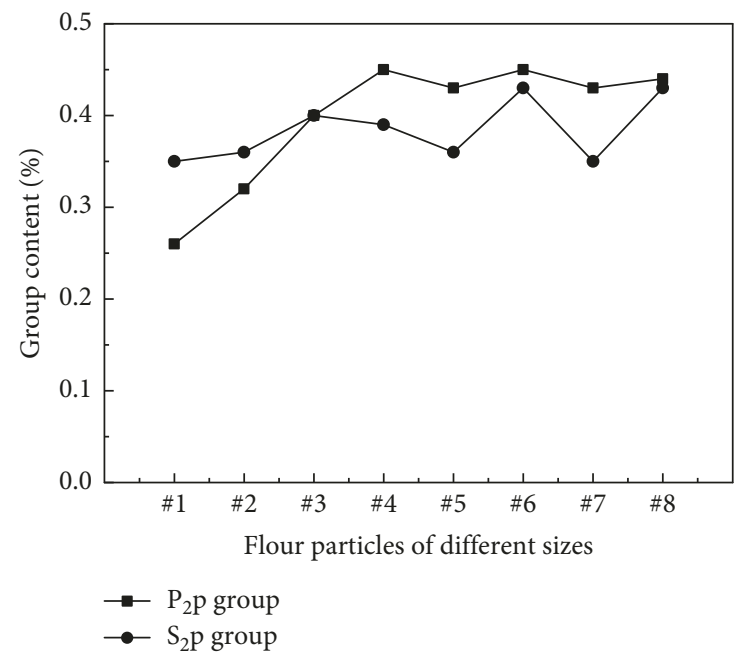

(d)

FIGURE 5: Variation of surface functional groups on the subpeaks of $\mathrm{C}_{1 \mathrm{~s}}(\mathrm{a}), \mathrm{O}_{1 \mathrm{~s}}(\mathrm{~b}), \mathrm{N}_{1 \mathrm{~s}}(\mathrm{c}), \mathrm{P}_{2 \mathrm{p}}$, and $\mathrm{S}_{2 \mathrm{p}}$ (d) of flour particles of different sizes. 
TABLE 5: The corresponding relationship between XPS decomposition peaks and the amino acids with side-chains containing corresponding functional groups.

\begin{tabular}{|c|c|c|}
\hline XPS decomposition peaks & Corresponding functional groups & Corresponding amino acid \\
\hline $\mathrm{C}_{1 \mathrm{~s}}$ Peak 2 & $\mathrm{C}-\mathrm{O}, \mathrm{C}-\mathrm{N}, \mathrm{O}-\mathrm{C}-\mathrm{O}, \mathrm{O}=\mathrm{C}-\mathrm{O}, \mathrm{O}=\mathrm{C}-\mathrm{N}$ & Tyr, Try, Ser, Thr \\
\hline $\mathrm{C}_{1 \mathrm{~s}}$ Peak $3+\mathrm{O}_{1 \mathrm{~s}}$ Peak $1+\mathrm{O}_{1 \mathrm{~s}}$ Peak 3 & $\mathrm{O}=\mathrm{C}-\mathrm{OH}, \mathrm{O}=\mathrm{C}-\mathrm{OR}, \mathrm{O}$ & Glu \\
\hline $\mathrm{C}_{1 \mathrm{~s}}$ Peak $2+\mathrm{O}_{1 \mathrm{~s}}$ Peak $1+\mathrm{N}_{1 \mathrm{~s}}$ peak 1 & $\begin{aligned} \mathrm{C}-\mathrm{O}, \mathrm{C}-\mathrm{N}, \mathrm{O}-\mathrm{C}-\mathrm{O}, \mathrm{O}=\mathrm{C}-\mathrm{O}, \mathrm{O}=\mathrm{C}-\mathrm{N}, \mathrm{O}=\mathrm{C}-\mathrm{OH}, \mathrm{O}=\mathrm{C}-\mathrm{N}, \mathrm{O}=\mathrm{C}-\mathrm{O}, \\
\mathrm{O}=\mathrm{C}-\mathrm{NH}, \mathrm{O}=\mathrm{C}-\mathrm{NH}_{2}\end{aligned}$ & Asn, Gln \\
\hline $\mathrm{N}_{1 \mathrm{~s}}$ peak 1 & $\mathrm{O}=\mathrm{C}-\mathrm{NH}, \mathrm{O}=\mathrm{C}-\mathrm{NH}_{2}$ & His, Arg \\
\hline $\mathrm{N}_{1 \mathrm{~s}}$ peak 2 & $\mathrm{C}-\mathrm{NH}_{3}^{+}$ & $\mathrm{L}$ \\
\hline & $-\mathrm{SH},-\mathrm{S}-$ & Met, Cys \\
\hline $\begin{array}{l}\mathrm{C}_{1 \mathrm{~s}} \text { Peak } 2+\mathrm{C}_{1 \mathrm{~s}} \text { Peak } 3+\mathrm{O}_{1 \mathrm{~s}} \text { Peak } 1+ \\
\mathrm{O}_{1 \mathrm{~s}} \text { Peak } 3+\mathrm{N}_{1 \mathrm{~s}} \text { peak } 1\end{array}$ & $\begin{array}{l}\mathrm{C}-\mathrm{O}, \mathrm{C}-\mathrm{N}, \mathrm{O}-\mathrm{C}-\mathrm{O}, \mathrm{O}=\mathrm{C}-\mathrm{O}, \mathrm{O}=\mathrm{C}-\mathrm{N}, \mathrm{O}=\mathrm{C}-\mathrm{OH}, \mathrm{O}=\mathrm{C}-\mathrm{OR}, \\
\mathrm{O}=\mathrm{C}-\mathrm{OH}, \mathrm{O}=\mathrm{C}-\mathrm{N}, \mathrm{O}=\mathrm{C}-\mathrm{O}, \mathrm{O}=\mathrm{C}-\mathrm{OH}, \mathrm{O}=\mathrm{C}-\mathrm{NH}, \mathrm{O}=\mathrm{C}-\mathrm{NH}_{2}\end{array}$ & $\begin{array}{c}\text { Tyr, Try, Ser, Thr, Asp, GluAsn, } \\
\text { Gln, His, Arg }\end{array}$ \\
\hline
\end{tabular}

\section{Conclusions}

The chemical composition distribution of flour particles of different size sieved by the same native flour was analyzed in this study. Significant differences existed in their particle microstructure, protein composition, and starch composition, proving that flour particles of different sizes must have different quality characteristics. According to the distribution rule in the eight samples, proteins with different solubility as well as amino acids had different distribution in the flour particles of different sizes. All these results implied that flour particles of different sizes might be formed from different positions of the wheat endosperm during wheat processing, leading to the differences in quality. The present study also demonstrated that the surface chemical composition had no correlation with the bulk chemical composition, and they would affect the quality of flour independently.

\section{Abbreviations}

SEM: Scanning electron microscopy

XPS: X-ray photoelectron spectroscopy.

\section{Data Availability}

The data used to support the findings of this study are included within the article.

\section{Conflicts of Interest}

The authors declare no competing financial interests.

\section{Acknowledgments}

The authors gratefully acknowledge financial support from the National Natural Science Foundation of China (Grant No. 31471675) and the Major Science and Technology Special Projects in Henan Province (Grant No. 141100110900).

\section{Supplementary Materials}

Figure S1: particle size distribution of different flour samples with the cumulative particle size distribution (a) and interval distribution (b). Figure S2: distribution trend of amino acids in flour particles of different sizes. Figure S3: correlation between function groups content by surface composition analysis and the corresponding amino acid in bulk composition analysis. (Supplementary Materials)

\section{References}

[1] H. Goesaert, K. Brijs, W. S. Veraverbeke, C. M. Courtin, K. Gebruers, and J. A. Delcour, "Wheat flour constituents: how they impact bread quality, and how to impact their functionality," Trends in Food Science and Technology, vol. 16, no. 1-3, pp. 12-30, 2005.

[2] Y.-C. Huang and H.-M. Lai, "Noodle quality affected by different cereal starches," Journal of Food Engineering, vol. 97, no. 2, pp. 135-143, 2010.

[3] S.-H. Park, J. D. Wilson, and B. W. Seabourn, "Starch granule size distribution of hard red winter and hard red spring wheat: its effects on mixing and breadmaking quality," Journal of Cereal Science, vol. 49, no. 1, pp. 98-105, 2009.

[4] L. Marchetti, M. Cardós, L. Campaña, and C. Ferrero, "Effect of glutens of different quality on dough characteristics and breadmaking performance," LWT-Food Science and Technology, vol. 46, no. 1, pp. 224-231, 2012.

[5] E. L. Sliwinski, P. Kolster, A. Prins, and T. v. Vliet, "On the relationship between gluten protein composition of wheat flours and large-deformation properties of their doughs," Journal of Cereal Science, vol. 39, no. 2, pp. 247-264, 2004.

[6] K. Ambrose, "Particle size analysis of two distinct classes of wheat flour by sieving," Transactions of the ASABE, vol. 57, pp. 151-159, 2014.

[7] S. Mmohamad, C. Gaiani, J. Scher, B. Cuq, J. J. Ehrhardt, and S. Desobry, "Impact of re-grinding on hydration properties and surface composition of wheat flour," Journal of Cereal Science, vol. 49, pp. 134-140, 2009.

[8] H. Tao, P. Wang, F. Wu, Z. Jin, and X. Xu, "Particle size distribution of wheat starch granules in relation to baking properties of frozen dough," Carbohydrate Polymers, vol. 137, pp. 147-153, 2016.

[9] J. Bressiani, T. Oro, G. S. Santetti et al., "Properties of whole grain wheat flour and performance in bakery products as a function of particle size," Journal of Cereal Science, vol. 75, pp. 269-277, 2017.

[10] D. W. Hatcher, M. J. Anderson, R. G. Desjardins, N. M. Edwards, and J. E. Dexter, "Effects of flour particle size and starch damage on processing and quality of white salted noodles," Cereal Chemistry Journal, vol. 79, no. 1, pp. 64-71, 2002.

[11] E. D. L. Hera, C. M. Rosell, and M. Gomez, "Effect of water content and flour particle size on gluten-free bread quality 
and digestibility," Food Chemistry, vol. 151, pp. 526-531, 2014.

[12] N. H. Oh, P. A. Seib, K. F. Finney, Y. Pomeranz, and V. Noodles, "Determination of optimum water absorption of flour to prepare oriental noodles," Veterinary Parasitology, vol. 95, pp. 179-186, 1986.

[13] P. G. Rouxhet, A. M. Misselyn-Bauduin, F. Ahimou et al., "XPS analysis of food products: toward chemical functions and molecular compounds," Surface and Interface Analysis, vol. 40, no. 3-4, pp. 718-724, 2008.

[14] M. Saad, C. Gaiani, M. Mullet, J. Scher, and B. Cuq, "X-ray photoelectron spectroscopy for wheat powders: measurement of surface chemical composition," Journal of Agricultural and Food Chemistry, vol. 59, no. 5, pp. 1527-1540, 2011.

[15] J. J. Fitzpatrick and L. Ahrné, "Food powder handling and processing: industry problems, knowledge barriers and research opportunities," Chemical Engineering and Processing: Process Intensification, vol. 44, no. 2, pp. 209-214, 2005.

[16] C. Gaiani, J. J. Ehrhardt, J. Scher, J. Hardy, S. Desobry, and S. Banon, "Surface composition of dairy powders observed by $\mathrm{X}$-ray photoelectron spectroscopy and effects on their rehydration properties," Colloids and Surfaces B: Biointerfaces, vol. 49, no. 1, pp. 71-78, 2006.

[17] E. H. J. Kim, X. D. Chen, and D. Pearce, "Melting characteristics of fat present on the surface of industrial spray-dried dairy powders," Colloids and Surfaces B: Biointerfaces, vol. 42, no. 1, pp. 1-8, 2005.

[18] E. H.-J. Kim, X. D. Chen, and D. Pearce, "Effect of surface composition on the flowability of industrial spray-dried dairy powders," Colloids and Surfaces B: Biointerfaces, vol. 46, no. 3, pp. 182-187, 2005.

[19] E. H.-J. Kim, X. D. Chen, and D. Pearce, "Surface characterization of four industrial spray-dried dairy powders in relation to chemical composition, structure and wetting property," Colloids and Surfaces B: Biointerfaces, vol. 26, no. 3, pp. 197-212, 2002.

[20] J. J. Nijdam and T. A. G. Langrish, "The effect of surface composition on the functional properties of milk powders," Journal of Food Engineering, vol. 77, no. 4, pp. 919-925, 2006.

[21] Y. V. WU, A. C. Stringfellow, and J. A. Bietz, "Relation of wheat hardness to air-classification yields and flour particle size distribution," Cereal Chemistry, vol. 67, no. 5, pp. 421427, 1990.

[22] L. Shi, W. Li, J. Sun et al., "Grinding of maize: the effects of fine grinding on compositional, functional and physicochemical properties of maize flour," Journal of Cereal Science, vol. 68, pp. 25-30, 2016.

[23] G. Branković, V. Dragičević, D. Dodig, D. KnežEvić, B. Kobiljski, and G. ŠurlanMomirović, "Albumin content in bread wheat (Triticum aestivum L.) and durum wheat (Triticum durum Desf.) as affected by the environment," Zemdirbyste, vol. 102, no. 3, pp. 281-288, 2015.

[24] K. R. Preston, O. M. Lukow, and B. Morgan, "Analysis of relationships between flour quality properties and protein fractions in a world wheat collection," Cereal Chemistry, vol. 69, pp. 560-567, 1992.

[25] I. Slađana, B. Miroljub, and P. I. Mirjana, "Genetic variability of albumin-globulin content, and lipoxygenase, peroxidase activities among bread and durum wheat genotypes," Genetika, vol. 43, no. 3, pp. 503-516, 2011.

[26] I. Rombouts, L. Lamberts, I. Celus, B. Lagrain, K. Brijs, and J. A. Delcour, "Wheat gluten amino acid composition analysis by high-performance anion-exchange chromatography with integrated pulsed amperometric detection,"
Journal of Chromatography A, vol. 1216, no. 29, pp. 5557 5562, 2009.

[27] L.-K. Liu, D. F. Becker, and J. J. Tanner, "Structure, function, and mechanism of proline utilization A (PutA)," Archives of Biochemistry and Biophysics, vol. 632, pp. 142-157, 2017.

[28] B. Berton, J. Scher, F. Villieras, and J. Hardy, "Measurement of hydration capacity of wheat flour: influence of composition and physical characteristics," Powder Technology, vol. 128, no. 2-3, pp. 326-331, 2002.

[29] W. Bae, B. Lee, G. G. Hou, and S. Lee, "Physicochemical characterization of whole-grain wheat flour in a frozen dough system for bake off technology," Journal of Cereal Science, vol. 60 , no. 3 , pp. 520-525, 2014.

[30] V. Landillon, D. Cassan, M.-H. Morel, and B. Cuq, "Flowability, cohesive, and granulation properties of wheat powders," Journal of Food Engineering, vol. 86, no. 2, pp. 178-193, 2008.

[31] P. L. Russell, B. M. Gough, P. Greenwell, A. Fowler, and H. S. Munro, "A study by ESCA of the surface of native and chlorine-treated wheat starch granules: the effects of various surface treatments," Journal of Cereal Science, vol. 5, no. 1, pp. 83-100, 1987.

[32] H. Tao, P. Wang, B. Ali, F. Wu, Z. Jin, and X. Xu, "Structural and functional properties of wheat starch affected by multiple freezing/thawing cycles," Starch-Stärke, vol. 67, no. 7-8, pp. 683-691, 2015. 

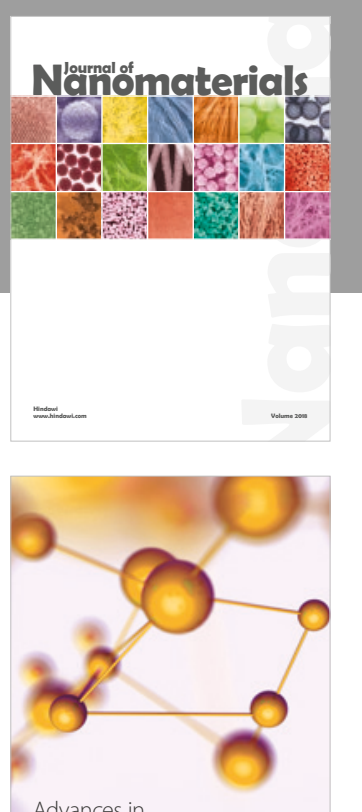

Physical Chemistry
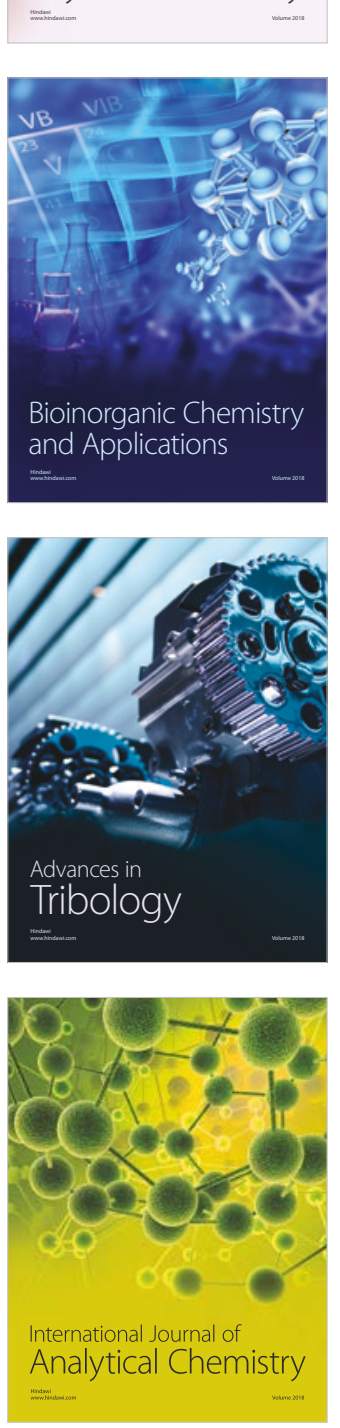

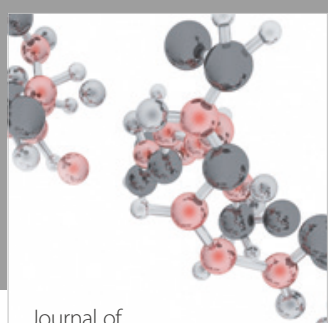

Analytical Methods

in Chemistry

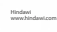

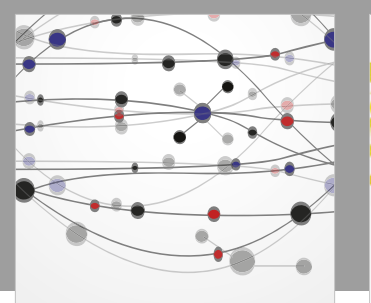

The Scientific World Journal

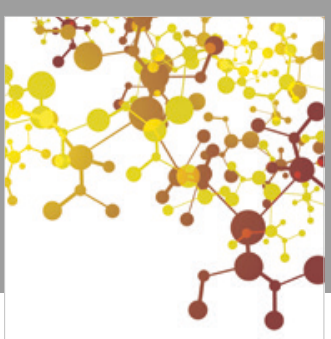

Journal of

Applied Chemistry
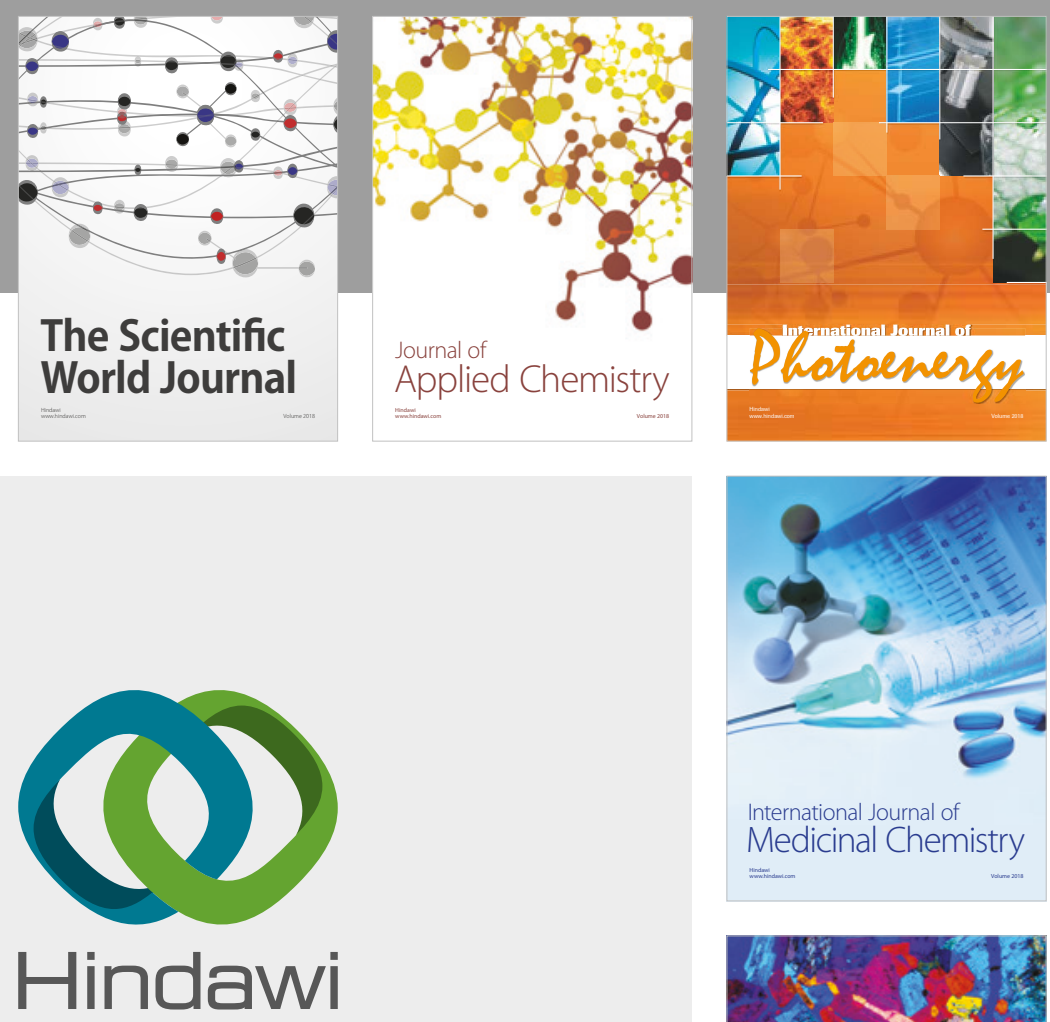

Submit your manuscripts at

www.hindawi.com
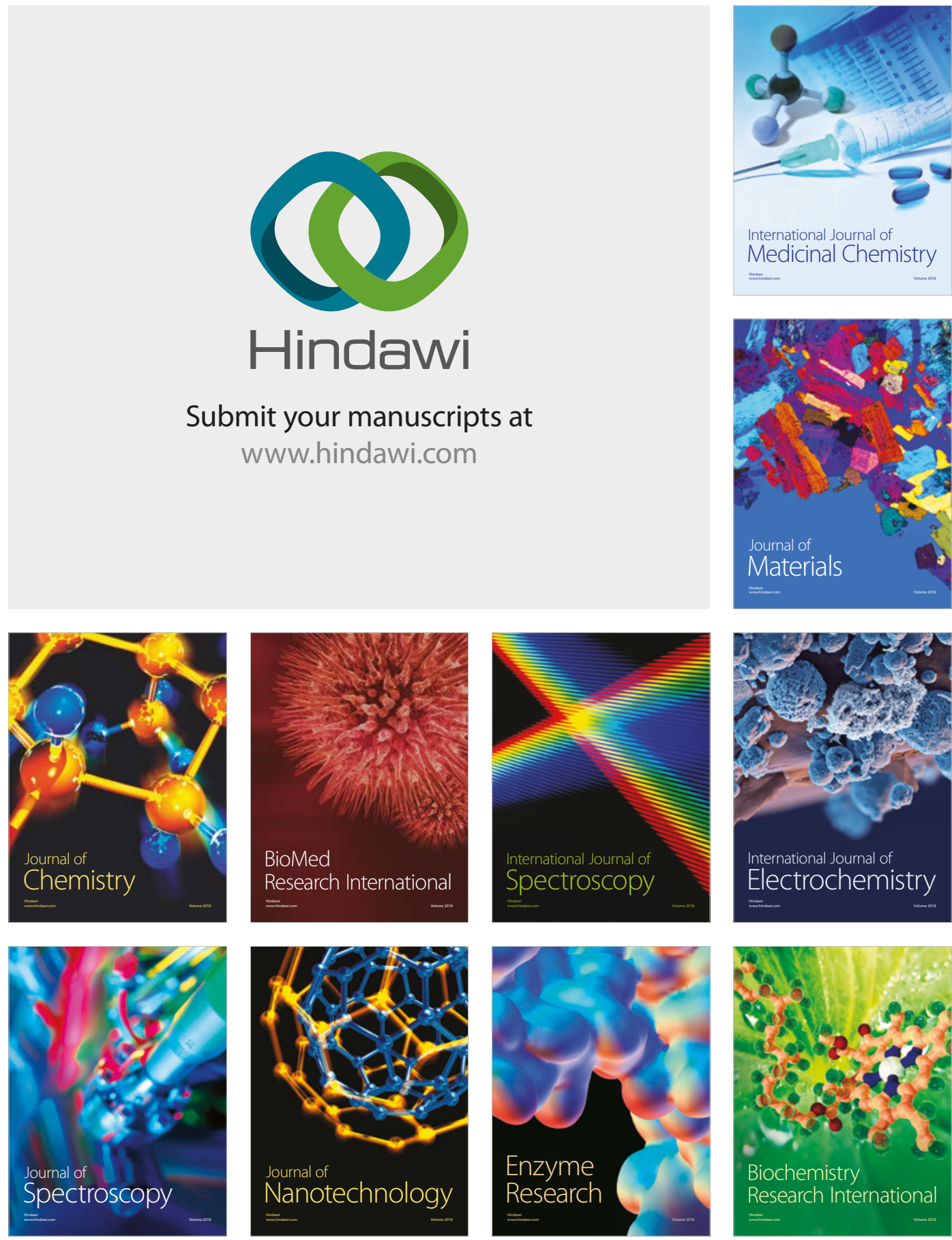
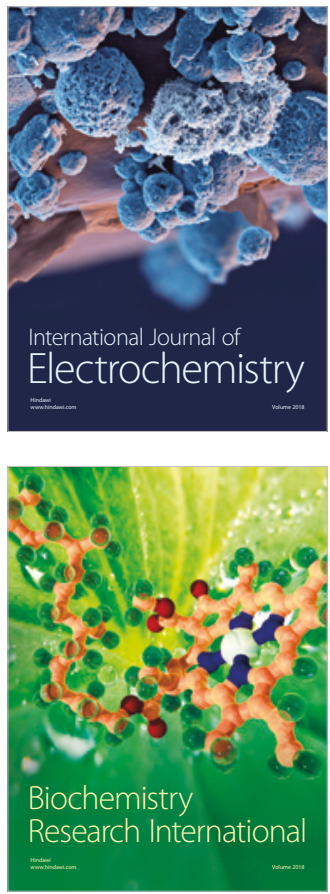